\title{
ETHNIC NATION NO MORE? MAKING SENSE OF GERMANY'S NEW STANCE ON DUAL CITIZENSHIP BY BIRTH
}

\author{
Elke Winter, Annkathrin Diehl, and Anke Patzelt \\ University of Ottawa
}

\begin{abstract}
While Germany does not allow dual citizenship in principle, since 23 November 2014, children born on German territory to non-German parents are no longer forced at the age of 23 to choose between German citizenship or that of their parents. Rather, they will be able to hold dual citizenship indefinitely. While this may be a far cry from more liberal dual citizenship policies in other countries, the progressive reform of Germany's citizenship law gains its specific meaning from that country's tormented history of ethnic nationhood and blood-based citizenship. It is also striking at a time when many countries in the Western world are moving towards more restrictive immigration and citizenship policies. In this paper, we argue that the abrogation of the Optionspflicht [the duty to choose] constitutes a step in leaving behind the country's notorious tradition of constituting an "ethnic nation.” Our analysis confirms Christian Joppke's claim that politics and party ideologies matter for the "de-ethnicization" and "re-ethnicization" of citizenship, simultaneous processes that are neither linear nor necessarily path-dependent.
\end{abstract}




\section{Introduction $^{1}$}

As Canada and other Western countries are implementing more restrictive immigration and citizenship policies, Germany seems to be moving in the opposite direction. Does a recent amendment to Germany's citizenship law constitute a step in leaving behind the country's notorious tradition of constituting an "ethnic nation?"

On November 13, 2014, the Optionspflicht [the duty to choose] ${ }^{2}$ was abolished by law (Bundesanzeiger 2014). The Optionspflicht was initially introduced in 2000 as part of the new German Citizenship Act. It granted dual citizenship to children born on German soil of foreign parents. This regulation was a major advancement on Germany's restrictive citizenship law, which traditionally relied on filiation (jus sanguinis). For the first time, the principle of territorybased citizenship (jus soli) was introduced; however, it was linked to two conditions: Firstly, one of the parents had to be living in Germany under a permanent residency status for at least eight years (Staatsbürgerschaftsgesetz 2000, paragraph \$4 section 3(1)). Secondly, by the age of 23, these children had to decide whether they wanted to keep their German citizenship or take up the citizenship passed down to them by their parents (Staatsbürgerschaftsgesetz 2000, paragraph $\S 29)$. This need to select one nationality only is understood as Optionspflicht.

With the acceptance of the new bill, entitled "Zweites Gesetz zur Änderung des Staatsangehörigkeitsgesetzes" (Second law on the modification of the Citizenship Act), the German Bundestag (Lower House of the German Parliament) abolished the Optionspflicht ${ }^{3}$ for the majority of people currently affected by this regulation, thus allowing them to hold dual citizenship indefinitely (Deutscher Bundestag 2014).

While this may be a far cry from the fairly liberal citizenship legislation in settler societies such as Canada, the progressive reform of Germany's citizenship law gains its specific meaning from that country's tormented history of ethnic nationhood and blood-based citizenship. It is also striking at a time when many countries in the Western world are moving towards more restrictive immigration and citizenship policies.

In this paper, we will explain Germany's recent citizenship legislation by situating it within the country's historical and (recent) political context. Specifically, we aim to answer the following research questions: To what extent is the country's new stance on dual citizenship by birth a step away from its notorious legacy as an "ethnic nation?” How can this new stance be explained? The concepts of "ethnic" and "civic" nationhood, reinstated by Brubaker in 1992, as well as

\footnotetext{
${ }^{1}$ This research benefitted from financial support provided by the Social Sciences and Humanities Research Council of Canada (Standard Faculty Research Grant and Canada-Europe Transatlantic Knowledge Cluster). The authors thank the anonymous reviewers for very helpful comments and assume full responsibility for all remaining errors.

${ }^{2}$ The words Optionspflicht [the duty to choose] and Optionsregelung [the regulation requiring a choice] refer to the same legal provision; they will be used interchangeably. Members of the German opposition also refer to this provision as Optionszwang [the obligation to choose].

${ }^{3}$ Out of the 569 members of the parliament who participated in the vote on July 3, 2014, 461 voted in favour of the legislation draft, whereas 108 voted against it (Deutscher Bundestag 2014a).
} 
Joppke's critique of Brubaker mobilizing the notions of "de-ethnicization" and "re-ethnicization" will be used as the theoretical framework for this discussion.

\section{Theoretical Framework}

According to Brubaker's (1992) seminal work, the type of nationhood that has historically informed a given political community, as well as the relative weight that is given to ethnicity within this understanding of nationhood, continues to inform citizenship policy. Defined as full membership in a political community, citizenship is based on claims to shared belonging, usually nationhood, as well as on claims to equal rights, duties, and status guaranteed by a sovereign state.

Brubaker's argument has famously given rise to two opposing ideal types: that of the "ethnic nation," based primarily on citizenship through filiation (jus sanguinis) and a communal understanding of nationhood, and that of the "civic nation," based on shared political will and non-ethnic, associative characteristics, such as unconditional jus soli (citizenship through birth in the territory). Within this definitional scheme, Germany had come to represent the prototype of the "ethnic nation."

Disputing the value of (ethnic versus civic) "national models" for research on citizenship, Joppke (2003) argues that ethnic and civic dimensions of citizenship should neither be understood in linear terms nor be viewed as a continuum. Rather, they exist simultaneously and in constant tension: "[a] state qua membership unit is a fundamentally ethnic institution because membership is usually ascribed at birth" (435) and continues to exist "irrespective of a member's contingent location and movements in space" (431). At the same time, the state is also "a territorial unit, whose integrative measures in an age of universal human rights have to become increasingly abstract and procedural” (431).

Joppke (2003, 436) defines "de-ethnicization" as "the process of facilitating the access to citizenship, either [...] in terms of liberalized naturalization procedures, or through adding jus soli elements to [...] birth-attributed citizenship." "A third element of de-ethnicized citizenship is an increasing toleration of dual citizenship" (441). Furthermore, "de-ethnicization” requires the "decoupling of the state from [illiberal forms of] nation-building" (437). It is contingent on the governing party’s ideology; it is most likely to occur under left-leaning parties (ibid.).

Overall, Joppke holds that, in Western immigrant-receiving states, the trend has been towards the "de-ethnicization” (2003) and liberalization (2007) of citizenship acquisition (through jus soli, naturalization, and toleration of dual citizenship) with very limited forms of "re-ethnicization" in order to avoid citizenship loss (through strengthening jus sanguinis provisions for expatriates and toleration of dual citizenship, which is interpreted as "re-ethnicization" from the point of view of sending states).

However, the potential of re-ethnicization remains present. It "is grounded in the fact that states are not just territorial but membership units” (Joppke 2003, 443). Specifically, "re-ethnicization” of citizenship occurs when criteria of inclusion/exclusion are explicitly or implicitly based on 
ascribed ethnic attributes, such as skin colour, religion, place of birth, language, culture, or dress. It is most likely to occur under right-leaning political parties in power (446).

Against this backdrop, we inquire a) whether the abrogation of the Optionspflicht can be interpreted as “de-ethnicization" of citizenship, b) whether this confirms Joppke's claim that politics and party ideologies matter, and c) to what extent the recent legislation means that Germany has left its historical roots of being an "ethnic nation."

\section{The History of Citizenship in Germany}

\section{From ethnic to civic nation?}

According to astute observers, at the turn of the $21^{\text {st }}$ century, Germany has changed from being an "ethnic nation" to being a country embracing "universalistic immigrant integration" (Heckmann 2003, 45). A brief look into Germany’s history can clarify this statement.

After the Second World War, the Federal Republic maintained a centralized citizenship law, which had been implemented in 1913. This law made the principle of descent (jus sanguinis) the only basis of citizenship, with the territorial principle (jus soli) completely absent. On the one hand, this afforded refugees and displaced persons of German background (Auslandsdeutsche) settlement rights. On the other hand, "guest workers" entering the Federal Republic mainly during the 1960s, coming from southern European countries and, primarily, Turkey, were excluded from this right. They were perceived as "foreigners" who were staying in the country only on a temporary basis and were expected to return when recession set in. Not being of "German blood," their children, even if born on German soil, were denied citizenship or even an easy or automatic naturalization.

Remaining unrevised, after the demise of the German Democratic Republic in 1989, Germany's citizenship law automatically granted citizenship to all Germans from the GDR (Übersiedler). Additionally, during the 1990s, large numbers of so-called Aussiedler - "ethnic Germans” from Eastern Europe and the former Soviet Union - were granted citizenship rights in Germany solely based on their German descent. At the same time however, immigrants of non-German background who had been living in Germany for a long time, sometimes several decades, became increasingly ethnicized in public discourse. In January 1991, the admission of non-EU migrants was restricted through a reform of the Foreigners' Law (Ausländergesetz), and in 1993, anti-immigration rhetoric culminated in a restriction of the constitutionally-guaranteed right of asylum. As mentioned in the theoretical framework, this context inspired Rogers Brubaker's work in the 1990s. In the wake of his groundbreaking study, it became common to identify Germany as the prototype of an "ethnic nation.”

Ultimately, national and international criticism of ethnic exclusionism, as well as increasing discomfort with large disenfranchised migrant populations, produced a situation where the status quo with respect to German citizenship legislation was politically no longer defendable. Thus, when a new government was elected in 1998, the two parties in power - the Social Democrats and the Green Party - finally acknowledged the fact that Germany had become a de facto 
"country of immigration." As a result of this change in perspective, the coalition parties proposed to reform Germany's citizenship law. They suggested introducing the principle of jus soli and dual citizenship, thus, on the one hand, granting citizenship to all children born on German soil, and on the other hand, giving non-Germans wishing to naturalize in Germany the possibility of keeping their previous citizenship, as well.

This proposal, however, was not put into action, as it was blocked by the opposition of the Christian Democrats (CDU/CSU), who saw dual citizenship as a danger to the successful integration of immigrants into the country, arguing that it would undermine their loyalty to Germany. Furthermore, they claimed that such a reform would increase immigration rates to Germany, and additionally, would result in a priority treatment of migrants over "Germans." In order to underline their position, the party initiated a signature campaign against dual citizenship. This campaign ran at the same time as the provincial elections in the Land Hessen took place in February 1999, and it was a success for the Christian Democrats. Not only were they able to win the elections in Hessen, but as a result of this, they also won a majority in the Bundesrat (Upper House of the German Parliament). The new German Citizenship Act that emerged out of subsequent negotiations came into effect on January 1, 2000.

Even though the new law did not include all the changes originally suggested by the Social Democrats and the Green Party, it still represented a major departure from previous policy. First and foremost, it became known for introducing the previously unprecedented territorial principle to the existing German citizenship law based on filiation. ${ }^{4}$ According to astute observers, the "introduction of jus soli clearly represents a seismic shift in German citizenship law and a firm change of direction away from its previous ethnocultural emphasis” (Green 2000, 114).

Second, the Act drastically reduced the mandatory residence requirement for the acquisition of German citizenship from 15 to eight years. ${ }^{5}$

Third, even though the Act did not introduce dual citizenship as a general option for everyone, some exceptions to this rule were implemented. For example, recognized refugees, individuals over 60 years old, and certain EU nationals now had access to dual citizenship. ${ }^{6}$ Furthermore, a temporary form of dual citizenship was introduced in $\$ 29$ of the Citizenship Act (Optionsregelgung; to be discussed below). This allowed children of non-German parents who were born on German soil to obtain dual citizenship upon birth. However, their dual status was only temporary and by the age of twenty-three, these individuals had to decide which of their two citizenships they wanted to maintain.

\footnotetext{
${ }^{4}$ This law stated that children born in Germany of non-German parents were to be granted German citizenship from birth, on the condition that one parent: a) had been legally resident for a period of eight years, and b) held either an unlimited resident permit (unbefristete Aufenthaltserlaubnis) for at least three years, or a residence entitlement (Aufenthaltsberechtigung). However, dual citizenship could only be held until the age of 23 when a decision had to be made.

${ }^{5}$ According to paragraph $\S 10$ of the Citizenship Act, a foreigner has a right to naturalization if (s)he has been a legal resident of Germany for eight years, commits to the liberal-democratic order of the Federal Republic of Germany, can take care of himself and his dependents, has a sufficient knowledge of German society and language, and gives up his previous citizenship.

${ }^{6}$ The Act allowed EU citizens to hold dual citizenship on the basis of reciprocity, i.e. on the condition that German citizens were also allowed to naturalize and to hold dual citizenship in the citizenship candidates' former home countries.
} 
There is widespread consent that the new Act introduced major changes to German citizenship legislation. Commentators maintain that "Germany has clearly moved 'up' from having the single most restrictive law before the 1999 reform to a more moderate policy today" (Howard 2012, 40). They agree that German citizenship can no longer be deemed "ethnic" in essence (Green 2000, 114).

\section{On the difficulty of being a "civic nation"}

Simplifying the requirements for naturalization and opening up possibilities for dual citizenship (at least in some cases), the 2000 Citizenship Act can be seen as a starting point in the movement towards more liberal citizenship policies in Germany. Despite this fact, many commentators remain critical, and some highlight that the reform "was also tempered by a significant 'restrictive backlash'” (Howard 2012, 39).

First, the Citizenship Act itself contained a number of restrictive dimensions. Candidates for naturalization are now asked to swear an oath declaring their loyalty to the "free and democratic character of the Constitution," as well as to demonstrate adequate knowledge of the German language through language tests (Ludvig 2004, 507). Both requirements were new and remained vaguely defined in both the act itself and subsequent legislation. As a consequence, since the implementation of naturalization requirements falls within the jurisdiction of the Bundesländer, there was substantial regional variation with respect to the interpretation of the naturalization criteria (see further below).

Second, by providing that German citizenship would be lost automatically if another citizenship was acquired, the Citizenship Act also closed a loophole in German citizenship legislation that had previously enabled migrants to renounce their citizenship, apply for German citizenship, and then reclaim it. For some time, Turkish migrants and authorities were either unaware of this change or felt they could safely ignore it. Only in 2003 did reapplications for Turkish citizenship drop sharply. By then, an estimated 48,000 Turkish migrants had taken advantage of the loophole and were in danger of losing their German citizenship (Bauböck 2010, 850).

Finally, while the act allows for multiple citizenship on an exceptional basis, as a rule, citizenship candidates must renounce their previous citizenship. This holds especially true for those who acquire citizenship through being born on German soil. According to the Optionsregelung, set out in $\S 29$ of the Citizenship Act, by the age of 23, these individuals have to decide whether they want to keep their German citizenship (acquired through the principle of jus soli) or whether to take up the citizenship passed down to them by their non-German parents (jus sanguinis). Furthermore, they automatically lose their German citizenship if they fail to revoke the citizenship passed down to them by their parents, or fail to provide evidence for this revocation. The stipulation that new citizens give up their previous citizenship was clearly the most controversial element of the new law (for details see Schönwälder and Triadafilopoulos 2012; Worbs et al 2012).

Despite these restrictions, immediately after the implementation of the new Act, there was a widespread assumption that the amount of naturalizations would rise. This resulted in renewed 
anxiety about safeguarding "German" values and traditions, mainly spurred on by members of the Christian Democrats. In March 2000, the government's plans to grant 20,000 work permits for IT specialists from non-European countries led to a debate on Germany's declining birthrate and the priority of educating native Germans over the immigration of "foreigners" (summarized in the slogan "Children, not Indians," Kinder statt Inder). In October of the same year, the Christian Democrats' approach to "integration" kick-started a debate about German "core culture” (Leitkultur) to which immigrants must adapt. ${ }^{7}$

In the wake of these debates, two amendments were implemented that made Germany's new citizenship law even more assimilatory (Green 2012, 177). The first amendment refers to the Residence Act (Aufenthaltsgesetz) (Bundesministerium der Justiz und für Verbraucherschutz 2004). This law constitutes Article 1 of Germany's first-ever Immigration Act (Zuwanderungsgesetz), which entered into force on January 1, 2005 (Bundesministerium des Innern 2004). ${ }^{8}$ Under its rules, those wishing to naturalize must complete an integration course, unless they are able to demonstrate their proficiency in the German language and knowledge of German society through other means (Winter and John 2010, 4-5). Completing an integration course reduces the standard residential requirement from eight years to seven. Since 2005, citizenship candidates have also been subject to a nationwide standardized obligatory query about their criminal background at the Federal Office of the Protection of the Constitution (Bundesverfassungsschutz). This is to determine whether applicants constitute a threat to Germany's constitutional order (Hailbronner 2006, 241).

In August 2007, eleven EU directives were implemented into German law (Gesetz zur Umsetzung aufenthalts- und asylrechtlicher Richtlinien der Europäischen Union). This resulted in the second amendment of the German Citizenship Act. First, the amended Citizenship Act now permits dual citizenship for all citizens of EU member-states and Switzerland. Second, it harmonizes targets for language competence (which had previously varied at the federal and the Länder level). As an added incentive for citizenship candidates demonstrating high levels of integration (e.g. language skills above level B1 GER), the residential requirement was reduced to six years. In addition, a harmonized federal citizenship test was introduced on September 1, 2008. Citizenship candidates are now obliged to demonstrate that they possess sufficient knowledge of the German societal and legal system. ${ }^{9}$ While the content and questions of the citizenship test have triggered much controversy (Michalowski 2011; Orgad 2009 - for different positions, see Goodman 2010; van Oers 2010), the integration courses and German language

\footnotetext{
${ }^{7}$ The debate about the German core culture subsided in 2001, only to return in 2006 and 2007 (cf. Palmowski 2008).

${ }^{8}$ The content of the Zuwanderungsgesetz was significantly watered down from the time of its original conception in August 2001 through to final approval by the Parliament in July 2004 (for a discussion, see Winter and John 2010).

${ }^{9}$ The citizenship test is based on a catalogue of 300 questions developed by the Institute for Quality Assurance in Education (IQB) and last updated on June 1, 2013. Candidates must correctly answer at least 17 out of 33 multiplechoice questions drawn from a catalogue of 310 questions on German history, culture, and politics (including 10 Land-specific questions). The test must be taken at specified Adult Education Centres. It takes 60 minutes and can be taken indefinitely. A 25 Euro fee to take the test is included as part of the 255 Euro general naturalization fee. According to $\S 10$ of Germany's citizenship law, the requirement to attend an integration course may be waived for immigrants who demonstrate a degree of proficiency in the German language and knowledge of German society. However, citizenship candidates must still take a citizenship test as part of the naturalization process (Winter and John 2010).
} 
instruction, which are largely paid for by the German government, seem to have been welcomed by immigrants (Will 2012).

Finally, under the amended Citizenship Act, the written statement of loyalty is to be supplemented by an oral declaration to be made by the candidate at the moment he or she receives the citizenship certificate.

\section{Debating Dual Citizenship by Birth}

After more than a decade since its introduction, the reform of Germany's citizenship law has not brought about the expected results. Originally, the 2000 Citizenship Act was to "enable those living permanently in Germany and their children born here to acquire full rights of citizenship" (Gerhard Schröder as quoted in Green 2012, 179). There was also a widespread expectation even anxiety for some - that there was going to be a significant increase in naturalizations.

In fact, the opposite has been the case. While there was a surge of 187,000 (2.57\%) in naturalizations in 2000, the year the new act came into effect, naturalization rates have been falling, even though the average residence period was on the rise (Green 2012). In 2011, Germany's naturalization rate was $1.44 \%$, with 106,896 individuals being naturalized (Statistisches Bundesamt Deutschland 2012). This is higher than annual naturalization rates under the old law in the 1970s and 1980s, when naturalization rates for the most part stayed below 1\% (Statistisches Bundesamt Deutschland 2012), but nothing compared to settler societies such as Canada, where they are consistently around the 75\% mark (OECD 2012).

In fact, after having implemented all of these legal changes, the trend has been that "long-term resident non-nationals are increasingly choosing not to naturalize” (Green 2012, 180). According to the Immigrant Citizens Survey, the following factors explain this tendency, in decreasing order: the renunciation of previous citizenship; the fact that immigrants see no difference between holding German citizenship and their current status in the country; that they do not plan to settle indefinitely in Germany; and that they feel the naturalization procedure is too difficult (Huddleston and Tjaden 2012; cf. Weinman et al 2011).

Furthermore, as of January 1, 2013, Germany was also losing citizens through automatic citizenship revocations. "Every three days a German youth turns into a foreigner," headlined an online migration magazine (MiGAZIN 2013). This was a result of the fact that the Optionspflicht, which had been in effect since January 1, 2000, had also been retroactively extended to all children who had been born in Germany by non-national parents since 1990 . Therefore, 2013 was the first year in which the first age-group of these until-then dual citizens was faced with the difficult decision of either renouncing the citizenship of their parents or their German citizenship upon their $23^{\text {rd }}$ birthday (3,413 in 2013; Bundesministerium des Innern 2012).

With the aim of counteracting this scenario, a number of motions proposing the abolishment of the Optionspflicht (Bündnis 90/Die Grünen), the acceptance of dual citizenship (SPD), and the facilitation of naturalization (Die Linke) were introduced by the opposition parties in the German 
Bundestag. However, these propositions were struck down by the then-governing coalition of Christian Democrats (CDU/CSU) and Liberals (FDP) during a debate in the Bundestag on June 5, 2013. The debate then proceeded in the German Bundesrat with the introduction of a bill proposing to allow for multiple citizenship and the abrogation of the Optionsregelung (Deutscher Bundesrat 2013). This bill was introduced by seven of the 16 Länder represented in the Bundesrat. After various discussions in the respective Bundesrat committees, the proposition of the bill was accepted in July and consequently forwarded to the Bundestag for further discussion (Deutscher Bundesrat 2013). The fact that the majority of the Länder in the Bundesrat were governed by the SPD alone or in coalition with the Green Party and/or the Left Party was a crucial factor in the proposal being accepted.

The debates in both Houses clearly showed a rift between party lines. While the opposition parties (SPD, Bündnis90/Die Grünen, and Die Linke) argued in favour of dual citizenship and the abrogation of Optionsregelung, the governing coalition of Liberals (FDP) ${ }^{10}$ and Christian Democrats (CDU/CSU) insisted upon the retention of single citizenship.

Two themes were particularly recurrent among members of the ruling parties. First, they maintained that the toleration of dual citizenship would lower immigrants' efforts to integrate and “devalue German citizenship" (Ole Schröder, Deutscher Bundestag 2013, 30592). ${ }^{11}$ Specifically, they argued that "only single citizenship promotes integration” (Ole Schröder, Deutscher Bundestag 2013, 30593). Dual or multiple citizenship, by contrast, was framed as entailing a conflict of loyalty - split between the "home country" and the country of settlement. Furthermore, it was viewed as causing political ambiguities. Both dimensions are present in the citation below:

\section{Dr. Ole Schröder (CDU), Parliamentary Secretary of State, Ministry of the Interior:}

We reject the general acceptance of multiple citizenship, as it can lead to serious problems. In our opinion, it is an expression of successful integration when an individual decides to take up German citizenship, thereby affirming his or her loyalty to this country. This is specifically underlined by giving up one's former citizenship [...]. We have to face reality: Multiple citizenship increases the risk that other states consider themselves a sort of parallel government for individuals who hold more than one citizenship. (Deutscher Bundestag 2013, 30592)

Members of the opposition parties, by contrast, argued against the logic of turning German-born citizens into foreigners: "We turn people, of whom the majority are even born here and therefore are born Germans, into foreigners in their own country. This is absurd” (Renate Künast [Bündnis 90/Die Grünen], Deutscher Bundestag 2013, 30590). According to this logic, dual citizenship does not hinder integration, but rather promotes it. The view taken here is that citizenship acquisition is a starting point for the integration process, and not its end; the integration of newcomers is said to be likely more successful when they are part of the citizenry:

\footnotetext{
${ }^{10}$ The FDP changed its position in the subsequent election campaign, but was not re-elected.

${ }^{11}$ All translations are the authors'.
} 


\section{Thomas Oppermann (SPD):}

Within the next 15 years, almost half a million young individuals in Germany will have to decide whether they want to remain Germans or whether they have to become foreigners. For two-thirds of these people, it is completely obvious that they want to keep both citizenships. What kind of signal are we sending to people who have been Germans for 23 years and who now have to renounce the citizenship of their parents and grandparents - in fact, who now have to renounce their heritage, in order to be able to remain German? What kind of citizenship law is this, which turns Germans into foreigners? It is an absurd citizenship law. (Deutscher Bundestag 2013, 30594)

\section{Bilkay Öney (SPD), Minister of Integration, Land Baden-Württemberg:}

First of all, I would like to state why naturalization is meaningful! Besides theoretical considerations regarding democracy, for me, there are major practical reasons related to integration policy. Studies have shown that naturalization boosts integration. We know that naturalized individuals achieve higher educational degrees, are less often unemployed, and earn higher incomes. (Deutscher Bundesrat 2013, 301)

Furthermore, it was argued that dual or even multiple citizenship is a normal state of affairs in the 21st century. In this sense, the Optionsregelung was viewed as being specifically discriminatory against Germans of Turkish origin. 18.5\% of Germany's almost 16 million "persons with a migratory background" (Menschen mit Migrationshintergrund) are of Turkish origin (Bundeszentrale für politische Bildung 2010). Since Turkey is not a European Union member state, they cannot benefit from the exemption to the requirement to renounce their previous citizenship that is afforded to European citizens. The opposition parties' insistence that the Optionspflicht constitutes a discrimination against immigrants of Turkish origin suggests that they tried to win over more immigrant voters. Arguments such as the one expressed below were particularly prominent in the debate:

\section{Sevim Dağdelen (DIE LINKE):}

Today, we are talking about two subjects that, as far as I am concerned, [...] feature many commonalities: On the one hand, we are talking about the Staatsangehörigkeitskeitsrecht (citizenship law) - keyword “Optionszwang.” On the other hand, we are talking about the German-Turkish Assoziationsrecht (law in favour of association). At first glance, these are different subjects. However, in my opinion, both subjects are linked in that they both feature discrimination against migrants, especially against Turkish citizens in Germany. You, dear colleagues, are world champions when it comes to demanding integration, but you fail at providing the basic necessary conditions for the integration of individuals in Germany. (Deutscher Bundestag 2013, 30597)

Eventually, the political debate was cut short due to the federal election on September 22, 2013, which resulted in a slim victory for the Christian Democrats (CDU/CSU). However, in order to 
be able to govern, the Christian Democrats needed to form a coalition. After long rounds of negotiations, they finally struck a deal with the Social Democrats. However, the way to forming this grand coalition was marked by intensive negotiations that lasted thirty-six days (Landeszentrale für politische Bildung Baden-Württemberg). One of the most debated topics during the coalition negotiations between the Christian Democrats and the Social Democrats was the abolition of the Optionspflicht (Zeit Online, November 7, 2013; Taz, November 7, 2013; Süddeutsche, November 7, 2013; Taz, November 24, 2013). Whereas the two Christian Democrat parties continued to oppose the abrogation of the Optionspflicht, the Social Democrats, on their side, insisted on the inclusion of this policy in the coalition treaty. Thus, the success of forming a new government was highly dependent on this question. In the end, the Christian Democrats gave in, the three parties agreed to a compromise, and the new coalition contract, signed by all three parties in November 2013, stipulated the abolition of Optionspflicht: "Immigrants shall become citizens. Those born and raised in Germany shall keep their German passport and shall not be forced to choose [between one citizenship and the other]" (Bundesregierung Deutschland 2013). However, for everyone else, the general intolerance of dual citizenship remains unchanged (Bundesregierung Deutschland 2013, 74).

On July 3, 2014, this stipulation was accepted by the Bundestag (Deutscher Bundestag 2014a) and was brought into force on November 13, 2014 (Bundesanzeiger 2014). The introduction of the new law abrogates the Optionspflicht for a majority of the people currently affected by this regulation. Children who were born on German territory and have obtained German citizenship on the basis of paragraph 4 section 3 ( $\S 4$ Absatz 3) of the Staatsangehörigkeitsgesetz (Citizenship Act) ${ }^{12}$ are now exempted from the Optionspflicht if they grew up in Germany.

In order to be considered as having grown up in Germany, one of the following conditions must be fulfilled: the individual has a) been living in Germany for eight years, b) attended a school in Germany for six years, or c) graduated from a school in Germany or obtained professional training in Germany. For everybody else, the Optionspflicht - the requirement to choose one nationality only - remains intact. ${ }^{13}$

\section{Discussion}

In this paper, we have asked 1) whether the abrogation of the Optionspflicht can be interpreted as “de-ethnicization" of citizenship, 2) whether this confirms Joppke's claim that politics and party ideologies matter, and 3) to what extent the recent legislation means that Germany has left its historical roots of being an "ethnic nation."

\footnotetext{
${ }^{12} \S 4$ Absatz 3 of the Citizenship Act states that children of non-German parents who are born in Germany obtain German citizenship if one of their parents has lived in Germany for eight years and holds permanent residency, or as a citizen of Switzerland or a relative of a Swiss citizen, has a residence permit on the basis of the agreement of free movement (from July 21, 1999) between the European Community and its member states, on the one hand, and the Swiss Confederation, on the other (Staatsbürgerschaftsgesetz 2000, §4 section 3[1]).

${ }^{13}$ There is, however, a hardship provision for individuals who can prove to have a similar connection to Germany to those who were born and raised on German soil, but who, for diverse reasons, do not fulfill the criteria mentioned above (Deutscher Bundestag. 2014. §29 section 1).
} 
First, evaluating the recent changes in Germany's citizenship legislation, one can certainly argue that a process of de-ethnicization as defined by Joppke (2003) has taken place over recent years. To reiterate, Joppke (2003) highlights three characteristics that determine the de-ethnicization process of citizenship: (a) "liberalized naturalization procedures" (436), (b) "adding jus soli elements to [...] birth-attributed citizenship" (436), and (c) "increasing toleration of dual citizenship” (441). With reference to the German case, these characteristics have at least been partly fulfilled:

(a) With the introduction of the 2000 Citizenship Act, the mandatory residence requirement for the acquisition of German citizenship was reduced from 15 to eight years. Subsequent changes of the Act in 2005 and 2007 further reduced residence requirements from eight to seven and then from seven to six years respectively, if the applicants showed a high level of integration, thus making naturalization procedures more liberal.

(b) The 2000 Citizenship Act also introduced jus soli elements to German citizenship legislation, which until that point had predominantly been based on jus sanguinis, allowing naturalization only by discretion.

(c) Furthermore, in the last fifteen years, Germany has increasingly tolerated dual citizenship. In 2000, the option of dual citizenship was introduced for the first time, and children born on German soil of non-German parents were allowed to obtain both German citizenship and the one passed down to them by their parents. Even though this was only on a temporary basis and they had to decide which of the citizenships to keep at the age of twenty-three (Optionspflicht), this was a major step in Germany's citizenship history. Additionally, since 2007, EU nationals have been allowed to hold dual citizenship. And finally, with the abrogation of the Optionspflicht in 2014, children of non-German parents born on German soil now no longer have to choose between one and the other, but can hold dual citizenship indefinitely.

To address our second question, in the case of Germany, party ideology and politics clearly impacted recent changes to Germany’s citizenship law. To reiterate, according to Joppke (2003, 437), processes of de-ethnicization are more likely to occur under left-leaning political parties, while processes of re-ethnicization are more likely to occur under right-leaning parties (446). This is reflected in the developments in Germany since the 1990s. It was only after the election of a more left-leaning government consisting of the Social Democrats and the Green Party in 1998 that Germany came to accept being a "de facto country of immigration" and that citizenship legislation became more liberal. The Social Democrats and the Green Party pushed for the introduction of jus soli, the acceptance of dual citizenship, and more streamlined naturalization procedures. However, these efforts were then blocked by the more right-leaning Christian Democrats (CDU/CSU). The subsequent changes to German citizenship were thus a fairly watered-down compromise between ideological standpoints and election politics of the parties involved.

The same can be said of the abrogation of the Optionspflicht in 2014: had the SPD not been part of the governing coalition, it is very likely that the Optionspflicht would not have been abolished by the CDU/CSU. Having come to adopt a liberal position towards dual citizenship over time, thereby strengthening its advantage over the CDU with respect to the so-called ethnic vote, the Social Democrats had made the abrogation of the Optionspflicht an election promise, which 
needed to be upheld in the coalition contract. With 2013 being the first year that this legal stipulation actually produced a concrete loss of citizenship among young Germans, timing and public opinion were on their side. The CDU's decision to accept the SPD's demand is reflective of the more centrist ideological positions aligned with chancellor Angela Merkel. ${ }^{14}$ Furthermore, the CDU is also aware that, in the years to come, electoral success will depend, in part, on winning over the votes of Germans with a so-called "migration background." With respect to defending the move vis-à-vis their more conservative-leaning constituency, as well as the more conservative CSU, they are able to claim that it had been forced upon them by the SPD.

This brings us to our third question, namely whether or not the recent legislation implies that Germany has left its historical roots of being an "ethnic nation.” The analysis conducted in this paper leads us to share Joppke's scepticism vis-à-vis the adequacy of the terms "ethnic" and "civic" nation. Dimensions of ethnic and civic nationhood exist simultaneously and in constant tension with each other. Especially in the globalized world of the $21^{\text {st }}$ century, it is becoming more and more difficult to find arguments in favour of a purely ethnic nation.

However, compared with citizenship debates in countries such as Canada that have never doubted their identity as an "immigration country," it remains obvious that, while Germany is on a progressive route towards liberalizing its citizenship regime, it still has quite a bit of catching up to do (Winter 2014). In this sense, the impact of national traditions on contemporary politics of citizenship should not be fully discarded. After all, Germany still does not tolerate dual citizenship in cases where it is not acquired through birth. Furthermore, the state remains an "ethnic" institution in so far as, for most if its citizens, membership is ascribed at birth and ends only with death. While it is also a territorial unit in which, strictly speaking, ethnic identities are becoming less important, it remains, at least for the vast majority of citizens, a community of destiny, belonging, and (some) interconnectedness based on shared values. As such, Joppke's (2003, 437) additional requirement for de-ethnicization, the "decoupling of the state from nationbuilding," may be neither realistic nor desirable, as it seems to imply the reformulation of citizenship in purely contractual terms. At least from the debates analyzed in this paper, it is clear that all of the arguments brought forth, whether they were left- or right-leaning, were aiming for the construction of an egalitarian and cohesive national society in times of globalization.

\section{Conclusion}

As this paper has shown, Germany is on a progressive route towards opening up its citizenship regime. The steps may be incremental, but the direction is forward. In conclusion, we want to underline three lessons to be drawn from the German debates on dual citizenship by birth. First, the abrogation of the Optionspflicht underlines once more the importance to grant citizenship rights to all individuals living within the territory of a given state. Excluding individuals who have been living in this state as permanent residents for years, sometimes decades, from political rights undermines the democratic system and creates a feeling of alienation and disconnection.

\footnotetext{
${ }^{14}$ We are indebted to one of the anonymous reviewers for drawing our attention to this fact.
} 
Second, the abrogation of the Optionspflicht highlights that loyalty cannot be legislated; it can only be acquired over time. It builds on trust, identification, and acceptance of individuals in the society in which they are living. By contrast, asking young Germans to decide between their German citizenship and the nationality of their parents at the age of 23 resulted in an instrumental interpretation of citizenship, encouraging individuals to base their decision about which citizenship to keep on rational factors, e.g. which country offers them better opportunities or resources, rather than on emotion and long-term experience, which in turn would promote loyalty.

Third, accepting dual citizenship is not about creating split identities and split loyalties, but rather about building bridges between different countries and cultures and accepting diversity. By abolishing the Optionspflicht, German parliamentarians made an opening move to create a society that can draw on and benefit from the resources (social, cultural, linguistic, etc.) of its individual members. Individuals speaking several languages and holding more than one passport are not a liability, but rather an asset for their country of residence. 


\section{REFERENCES}

Bauböck, Rainer. 2010. “Studying Citizenship Constellations.” Journal of Ethnic and Migration Studies, 36 ( 5), 847 - 859. doi: 10.1080/13691831003764375.

Brubaker, Rogers. 1992. Citizenship and Nationhood in France and Germany. Cambridge (MA): Harvard University Press.

Bundesanzeiger. 2014. Bundesgesetzblatt Teil 1, Nr. 52 vom 20.11.2014 Komplette Ausgabe. Accessed on March 23, 2015.

http://www.bgbl.de/banzxaver/bgbl/start.xav?startbk=Bundesanzeiger_BGBl\&start=//*\% 255B@attr_id=\%27bgbl114s1714.pdf\%27\%255D\#_bgbl_\%2F\%2F*[\%40attr_id\%3D \%27bgbl114052.pdf\%27]_1426450731005.

Bundesministerium der Justiz und für Verbraucherschutz. 2000. "Staatsangehörigkeitsgesetz (StAG).” Accessed on March 23, 2015. http://www.gesetze-im-internet.de/rustag/BJNR005830913.html.

Bundesministerium der Justiz und für Verbraucherschutz. 2004. “Aufenthaltsgesetz.” Accessed on March, 23 2015. http://www.gesetze-iminternet.de/aufenthg_2004/BJNR195010004.html\#BJNR195010004BJNG000101310.

Bundesministerium des Innern. 2004. “Zuwanderungsgesetz.” Accessed on March 23, 2015. http://www.bmi.bund.de/SharedDocs/Gesetzestexte/DE/Zuwanderungsgesetz.pdf;jsessio nid=60ABEE26CCFB941B7EAB886310E67371.2_cid364?__blob=publicationFile.

Bundesministerium des Innern. 2012. "Ergebnisse der Einbürgerungsstudie 2011 und der qualitativen Studie der Forschungsgruppe des Bundesamtes für Einbürgerunsverhalten.” Berlin, 22 June, 5 page website publication on file with authors.

Bundesregierung Deutschland. 2013. "Deutschlands Zukunft gestalten. Koalitionsvertrag zwischen CDU, CSU und SPD.” Berlin. Accessed on March 23, 2015. http://www.bundesregierung.de/Content/DE/StatischeSeiten/Breg/koalitionsvertraginhaltsverzeichnis.html.

Bundeszentrale für politische Bildung. 2010. "Die soziale Situation in Deutschland: Bevölkerung mit Migrationshintergrund I.” Accessed on March 23, 2015. http://www.bpb.de/nachschlagen/zahlen-und-fakten/soziale-situation-indeutschland/61646/migrationshintergrund-i.

Deutscher Bundesrat. 2013. "Plenarprotokoll. Stenographischer Bericht der 910. Sitzung (07.06.2013).” Accessed on March 23, 2015. http://www.bundesrat.de/SharedDocs/downloads/DE/plenarprotokolle/2013/Plenarprotok oll-910.pdf? blob=publicationFile\&v=4. 
Deutscher Bundestag. 2013. "Plenarprotokoll. Stenographischer Bericht der 242. Sitzung der 17. Wahlperiode (05.06.2013).” Accessed on March 23, 2015. http://dipbt.bundestag.de/doc/btp/17/17242.pdf.

Deutscher Bundestag. 2014. “Gesetzentwurf der Bundesregierung. Entwurf eines Zweiten Gesetzes zur Änderung des Staatsangehörigkeitsgesetzes. Drucksache 18/1312 (05.05.2014).” Accessed on March 23, 2015. http://dip21.bundestag.de/dip21/btd/18/013/1801312.pdf.

Deutscher Bundestag. 2014a. "Plenarprotokoll. Stenographischer Bericht der 46. Sitzung der 18. Wahlperiode (03.07.2014).” Accessed on March 23, 2015. http://dip21.bundestag.de/dip21/btp/18/18046.pdf.

Goodman, Sara Wallace. 2010. "Integration Requirements for Integration's Sake? Identifying, Categorising and Comparing Civic Integration Policies.” Journal of Ethnic and Migration Studies, 36 (5), 753 - 772. doi: 10.1080/13691831003764300.

Green, Simon. 2000. "Beyond Ethnoculturalism? German Citizenship in the New Millennium.” German Politics, 9 (3), 105-124. doi: 10.1080/09644000008404609.

Green, Simon. 2012. "Much ado about not-very-much? Assessing ten years of German citizenship reform.” Citizenship Studies, 16 (2), 173-188.

doi: 10.1080/13621025.2012.667610

Hailbronner, Kay. 2006. “Germany.” In Acquisition and Loss of Nationality. Volume 2: Country Analyses: Policies and Trends in 15 European Countries, edited by Rainer Bauböck, Eva Ersbøll, Kees Groenendijk and Harald Waldrauch, 213-251. Amsterdam: Amsterdam University Press.

Heckmann, Friedrich. 2003. "From Ethnic Nation to Universalistic Immigrant Integration: Germany.” In The Integration of Immigrants in European Societies: National Differences and Trends of Convergence, edited by Friedrich Heckmann and Dominique Schnapper, 45-78. Bamberg, Stuttgart: European Forum for Migration Studies (EFMS), Lucius \& Lucius.

Howard, Marc Morjé. 2012. “Germany’s Citizenship Policy in Comparative Perspective.” German Politics and Society, 30 (1), 39-51. doi: 10.3167/gps.2012.300103.

Huddleston, Thomas \& Jasper Dag Tjaden. 2012. Immigrant Citizens Survey: How immigrants experience integration in 15 European cities. Brussels: King Badouin Foundation and Migration Policy Group.

Joppke, Christian. 2003. “Citizenship between De- and Re-ethnicization.” European Journal of Sociology, 44( 3), 429-458. doi: 10.1017/S0003975603001346. 
Joppke, Christian. 2007. "Beyond National Models: Civic Integration Policies for Immigrants in Western Europe.” Western European Politics 30 (1), 1-22. doi: 10.1080/01402380601019613.

Landeszentrale für politische Bildung Baden-Württemberg. "Bundestagswahl am 22. September 2013.” Accessed on March 23, 2015. http://www.bundestagswahl-bw.de/.

Ludvig, Alice. 2004. "Why Should Austria be Different from Germany? The Two Recent Nationality Reforms in Contrast." German Politics, 13 (3), 499-515. doi: 10.1080/0964400042000287473.

Michalowski, Ines. 2011. "Required to assimilate? The content of citizenship tests in five countries.” Citizenship Studies, 15 (6-7), 749-768. doi: 10.1080/13621025.2011.600116.

MiGAZIN. 2013. "Optionspflicht: Alle drei Tage wird aus einem deutschen Jugendlichen ein Ausländer.” 13 June. Accessed on March 23, 2015. http://www.migazin.de/2013/06/13/optionspflicht-alle-tage-jugendlichen/.

OECD. 2012. “Settling.” In: OECD Indicators of Immigrant Integration 2012: OECD Publishing.

Orgad, Liav. 2009. "Illiberal Liberalism: Cultural Restrictions on Migration and Access to Citizenship in Europe.” American Journal of Comparative Law, 58 (1), 53-105. URL: http://www.jstor.org/stable/25652685.

Palmowski, Jan. 2008. "In search of the German nation: citizenship and the challenge of integration.” Citizenship Studies, 12 (6), 547-563. doi: 10.1080/13621020802450635.

Schönwälder, Karen, and Triadafilos Triadafilopoulos. 2012. “A Bridge or Barrier to Incorporation? Germany's 1999 Citizenship Reform in Critical Perspective.” German Politics and Society, 30 (1), 52-70. doi: 10.3167/gps.2012.300104.

Staatsbürgerschaftsgesetz. 2000. Accessed on March 27, 2015 http://www.gesetze-iminternet.de/bundesrecht/rustag/gesamt.pdf.

Statistisches Bundesamt Deutschland. 2012. Bevölkerung und Erwerbstätigkeit: Einbürgerungen. Wiesbaden: Statistisches Bundesamt. Accessed on March 23, 2015. https://www.destatis.de/DE/Publikationen/Thematisch/Bevoelkerung/MigrationIntegratio n/Einbuergerungen2010210117004.pdf? blob=publicationFile .

Süddeutsche. 2013. “Doppelpass entzweit Union und SPD”, November, 7. Accessed on March 21, 2015. http://www.sueddeutsche.de/politik/verhandlungen-zur-staatsbuergerschaftdoppelpass-entzweit-union-und-spd-1.1812917.

Taz. 2013a. "Keine Kompromisse”, November 7. Accessed on March 21, 2015. http://www.taz.de/!127031/. 
Taz. 2013b. “Gröhe könnte sich da was vorstellen”, November 24. Accessed on March 21, 2015. http://www.taz.de/Streitthema-doppelte-Staatsbuergerschaft/!128071/.

van Oers, Ricky. 2010. "Citizenship Tests in the Netherlands, Germany and the UK.” In A Redefinition of Belonging? Language and Integration Tests in Europe (Vol. 20), edited by Ricky van Oers, Eva Ersbøll, and Dora Kostakopoulou, 51-105. Leiden, Boston: Martinus Nijhoff Publishers.

Weinmann, Martin, Ina Becher \& Christian Babka von Gostomsk. 2012. Einbürgerungsverhalten von Ausländerinnen und Ausländern in Deutschland sowie Erkenntnisse zu Optionspflichtigen. Ergebnisse der BAMF-Einbürgerungsstudie 2011. (Vol. Forschungsbericht 15). Nürnberg: Bundesregierung Deutschlan; Bundesamt für Migration und Flüchtlinge.

Will, Anne-Kathrin. 2012. Deutsche Integrationsmaßnahmen aus der Sicht von Nicht-EUBürgern. Die Ergebnisse des Immigrant Citizens Survey für Deutschland. Berlin: Sachverständigenrat deutscher Stiftungen für Integration und Migration.

Winter, Elke. 2014. "Traditions of Nationhood or Political Conjuncture? Debating Citizenship in Canada and Germany.” Comparative Migration Studies, 2 (1), 29-56. doi: 10.5117/CMS2014.1.W INT.

Winter, Elke, \& Kristina John. 2010. "German Citizenship in the Context of the European Union: Recent Changes.” SSHRC Strategic Knowledge Cluster Canada-EU Transatlantic Dialogue Policy Brief. Accessed on March 23, 2015. http://labs.carleton.ca/canadaeurope/2010/policy-brief-a-new-approach-to-citizenshipand-integration-some-facts-about-recent-policy-changes-in-germany-by-elke-winter-andkristina-john/.

Worbs, Susanne, Antonia Scholz \& Stefanie Blicke. 2012. "Die Optionsregelung im Staatsangehörigkeitsrecht aus der Sicht von Betroffenen. Qualitative Studie.” In Bundesregierung Deutschland, edited by Bundesamt für Migration und Flüchtlinge, (Vol. Forschungsbericht 16). Nürnberg.

Zeit Online. 2013. "Streit über doppelte Staatsbürgerschaft wird Chefsache,” November 7. Accessed on March 21, 2015. http://www.zeit.de/politik/deutschland/2013-11/doppeltestaatsbuergerschaft-koalitionsverhandlungen-union-spd. 
Published by the Centre for European Studies at Carleton University, Ottawa, Canada Available online at: journals.carleton.ca/rera/index.php/rera

RERA is an electronic academic peer-reviewed journal that publishes graduate, post-graduate, and young scholarly works. Topics relate to the European Union, its Member States, the former Soviet Union, and Central and Eastern Europe. The journal is a joint project supported by the Canada-Europe Transatlantic Dialogue-a cross-Canada research network supported by the Social Sciences and Humanities Research Council of Canada (SSHRC)—along with the Institute of European, Russian and Eurasian Studies (Carleton University) and its associated research unit, the Centre for European Studies.

RERA aims to provide an accessible forum for research, to promote high standards of research and scholarship, and to foster communication among young scholars.

\section{Contact:}

Carleton University

The Centre for European Studies

1103 Dunton Tower

1125 Colonel By Drive

Ottawa, ON K1S 5B6

Canada

Tel: +01 613 520-2600 ext. 3117; E-mail: rera-journal@carleton.ca

\section{Creative Commons License}

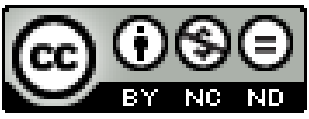

creativecommons.org/licenses/by-nc-nd/3.0

This Working Paper is licensed under a Creative Commons Attribution-Non-CommercialNo Derivs 3.0 Unported License (CC BY-NC-ND 3.0).

Articles appearing in this publication may be freely quoted and reproduced, provided the source is acknowledged. No use of this publication may be made for resale or other commercial purposes.

ISSN: 1718-4835

(C) 2015 The Author(s) 